\title{
Main Historical Actors
}

AYMÉ, GeNeral GeORges. Commander of French Indochina Army, July 1944-March 1945.

BAO DAI. Emperor of Annam until abdication in August 1945.

CHANG FA-KWEI, GENERAL. Commander of Chinese Fourth War Zone (Kwangsi and western Kwangtung provinces) during World War II.

Chiang kai-Shek, generalissimo. President of China.

CHU VAN TAN. Nung ethnic minority guerrilla leader, founder of small National Salvation Army north of Hanoi.

ChURChill, winston. Prime minister of Great Britain until July 1945.

DE GAUlLE, GeNeral Charles. Free French leader in London from June 1940, president of Algiers-based Committee of National Liberation 1943-44, president of provisional government in Paris from 1944. DECOUX, ADMIRAL JEAN. French governor-general of Indochina, 1940March 1945.

DuCoroy, navy CaPtain maurice. Head of Indochina General Commissariat for Physical Education, Sports, and Youth until March 1945.

DUONG DUC HIEN. Chairman of Hanoi General Student Association, founder of Vietnam Democratic Party in 1944, minister of youth in first DRV cabinet.

Hо CHI MINH. Senior member of ICP, founder of Viet Minh in 1941, chairman of National Liberation Committee announced in mid August 1945, president of Democratic Republic of Vietnam inaugurated 2 September 1945 . 
HOANG QUOC viET. Deputy to ICP General Secretary Truong Chinh, specializing in clandestine liaison. Dispatched to Cochinchina in late August 1945.

HSIAO WEN, GENERAL. Senior staff aide to General Chang Fa-kwei, responsible for Indochina affairs.

LUNG YÜN, GENERAL. Governor of Yunnan province, adjacent to Indochina.

MATSUSHITA MITSUHIRO. Japanese merchant long resident in Indochina. Wartime intermediary between Japanese officials and Cao Dai religious leaders.

MINODA FUIIO. Japanese governor of Cochinchina, March-August 1945.

MORdant, General eugène. Commander of French Indochina Army until July 1944, then head of de Gaulle's covert resistance organization in the colony until March 1945.

MOUNTBATTEN, ADMIRAL LORD LOUis. British supreme commander South East Asia, based at Kandy, Ceylon.

NGUYEN HAI THAN. Senior Vietnamese émigré participant in various Chinese-sponsored organizations, notably the Vietnam Revolutionary League.

NGUYEN KHANG. Member of the ICP Northern Region Committee, responsible for Hanoi operations.

NISHIMURA KUMAO. Japanese resident superior for Tonkin, MarchAugust 1945, as well as supreme counsellor to Phan Ke Toai, Tonkin imperial delegate.

Patti, CaPTain archimedes L.A. American OSS officer in China responsible for Indochina operations. First Allied representative to arrive in Hanoi, 22 August 1945.

Pham khaC hoE. Private secretary to Emperor Bao Dai.

PHAM NGOC THACH. Physician, leading Saigon intellectual in contact with both Japanese and ICP, chairman of Vanguard Youth organization, minister of health in first DRV cabinet.

PHAN ANH. Lawyer, prominent Hanoi intellectual, minister of youth in Imperial Vietnam government, April-August 1945. 
PHAN KE TOAI. Imperial delegate (Kham Sai) for Tonkin, May-August 1945.

roOsevelt, franklin D. President of the United States until death on 12 April 1945.

SABATtier, general Gabriel. French commander of Indochina Army contingents in Tonkin. Leads remnant units in retreat to China following 9 March 1945 Japanese coup.

SAINTENY, JEAN. Free French intelligence officer, head of Mission 5 in Kunming. Accompanies Archimedes Patti to Hanoi in August 1945.

TERAUCHI HISAICHI, FIElD MARShal COUNT. Commander of Japan's vast Southern Army Area, with headquarters in Singapore and subsequently Saigon.

THOMAS, MAJOR ALLISON K. Head of American OSS team parachuted to Ho Chi Minh's mountain headquarters in July 1945.

TON QUANG PHIET. Writer, principal of private school in Hue, covert ICP member, founder of New Vietnam Association, chairman of Thua Thien province people's committee in August 1945.

TRAN HUY LIEU. Journalist, ICP member, deputy chairman of National Liberation Committee in mid August 1945, minister of propaganda in first DRV cabinet.

TRAN TRONG KIM. Writer, historian, retired colonial education inspector, premier of Imperial Vietnam, April-August 1945.

TRAN vaN GIAU. Prominent ICP activist in Cochinchina, head of Southern Vietnam Uprising Committee in August 1945.

TRUMAN, HARRY S. Vice president of the United States, sworn in as president following Franklin Roosevelt's death in April 1945.

TRUONG CHINH. Secretary-general of the ICP from 1941, with clandestine headquarters in the Red River Delta.

TSUCHIHASHI YŪICHI, GENERAL. Commander of Japanese Thirty-eighth Army in Indochina from December 1944. Governor-general of Indochina, March-August 1945.

tsukamoto takeshi, CONSUl GeNeral. Civilian deputy to General Tsuchihashi in latter's capacity as Indochina governor-general, MarchAugust 1945. 
xx / Main Historical Actors

vo NGUYEN GIAP. Teacher, ICP member, lieutenant to Ho Chi Minh, founder of small Vietnam Propaganda and Liberation Army in December 1944, commander of Liberation Army from April 1945. Minister of interior in first DRV cabinet.

vU HONG KHANH. Leader of Vietnam Nationalist Party adherents in Kunming and along Yunnan railway.

WEDEMEYER, GENERAL ALBERT. American deputy chief of staff to Lord Mountbatten in Ceylon until November 1944, when appointed chief of staff to Generalissimo Chiang Kai-shek and commander of U.S. Army Forces, China Theater.

YOKOYAMA MASAYUKI, AMBASSADOR. Japanese supreme adviser to Emperor Bao Dai, March-August 1945. 